Revue bibliographique pour le domaine irano-aryen

Volume 37-38-39 | 2018

Comptes rendus des publications de 2014-2016

\title{
Touraj Daryaee. « From Terror to Tactical Usage: Elephants in the Partho-Sasanian Period»
}

\section{Rika Gyselen}

\section{(2) OpenEdition \\ 1 Journals}

\section{Édition électronique}

URL : http://journals.openedition.org/abstractairanica/42640

DOI : 10.4000/abstractairanica.42640

ISBN : 1961-960X

ISSN : 1961-960X

Éditeur :

CNRS (UMR 7528 Mondes iraniens et indiens), Éditions de l'IFRI

Référence électronique

Rika Gyselen, «Touraj Daryaee. «From Terror to Tactical Usage: Elephants in the Partho-Sasanian Period » », Abstracta Iranica [En ligne], Volume 37-38-39 | 2018, document 13, mis en ligne le 10 mars 2018, consulté le 27 septembre 2020. URL : http://journals.openedition.org/abstractairanica/42640 DOI : https://doi.org/10.4000/abstractairanica.42640

Ce document a été généré automatiquement le 27 septembre 2020

Tous droits réservés 


\title{
Touraj Daryaee. « From Terror to Tactical Usage: Elephants in the Partho-Sasanian Period»
}

\author{
Rika Gyselen
}

\section{RÉFÉRENCE}

Touraj Daryaee. « From Terror to Tactical Usage: Elephants in the Partho-Sasanian

Period ", in V. Sarkhosh Curtis, E. J. Pendleton, M. Alram et T. Daryaee (eds.), The

Parthian and Early Sasanian Empires: Adaptation and Expansion. Proceedings of a Conference in Vienna, 14-16 June 2012, Oxford \& Philadelphia, 2016, p. 36-41

1 L'objectif de cet article est de montrer que, contrairement à une opinion courante, l'emploi de l'éléphant à l'époque parthe est documenté. Aux nombreuses sources qui ont déjà été publiées sur l'image, la symbolique et le rôle de l'éléphant en Iran sassanide, l'auteur ajoute quelques sources littéraires pour l'époque parthe - un texte latin de Tacite et le Āyādgar-ī Zarēēān en moyen-perse mais dont l'origine remonte à la poésie épique antérieure à l'époque sassanide. Si l'éléphant est un symbole de la royauté comme le souligne l'auteur, on ne peut oublier qu'il est aussi celui de l'armée à l'époque d'Ohrmazd IV comme le met en évidence un sceau du dīwān des armées des quatre directions qui porte le motif d'un éléphant avec son cornac. 


\section{AUTEURS}

\section{RIKA GYSELEN}

CNRS, Mondes iranien et indien 